\title{
Perfluoroalkylation of alkenes and alkynes in water
}

\author{
Alvaro J. Vázquez, and Norma S. Nudelman* \\ Depto. Química Orgánica, Facultad de Ciencias Exactas y Naturales, Universidad de Buenos \\ Aires, Ciudad Universitaria- 1428 Buenos Aires, Argentina \\ E-mail:nudelman@qo.fcen.uba.ar
}

DOI: $\underline{\text { http://dx.doi.org/10.3998/ark.5550190.p009.091 }}$

\begin{abstract}
Perfluoroalkylation of alkenes and alkynes was performed using thermal initiation by ACCN (1,1'-azobis(cyclohexanecarbonitrile)) in water, with good yields. The procedure is simple and more ecofriendly that most of the methods published for the synthesis of related compounds. Using water (without any cosolvent or metal catalysts), it allows the synthesis of the addition products with medium to high yields.
\end{abstract}

Keywords: Perfluoroalkylation, radical addition, thermal initiation, reactions in water

\section{Introduction}

Owing to their strong carbon-fluorine bonds, perfluoroalkyl and polyfluoroalkyl compounds (PFAS), exhibit unique properties such as extremely high thermal and chemical stability. They are used in several industrial products as firefighting materials, alkaline cleaners, paints, non stick cookware, up-holstery, floor polishers, fume suppressants, semiconductors, photography films, pesticides, food packaging, etc. ${ }^{1}$ New types of fluorochemicals have been reported as useful for surface modification of various materials (clothes, leathers, domestic house-wares, papers, etc). ${ }^{2}$ Perfluoroalkyl compounds have been also described as greener surfactants, for a wide variety of industrial applications, ${ }^{3-5}$ and PFAS have been recently described as antifouling materials ${ }^{6-8}$ and epoxy resins. ${ }^{9}$

Though the role of these fluorine derivatives in various fields is generally recognized, a problem is the lack of selective and convenient fluoroalkylation methods tolerant to various functionalities, so active research is being devoted to the search of effective methodologies for the introduction of perfluoroalkyl moieties. ${ }^{10}$ Radical addition of perfluoroalkyl halides to carbon-carbon double bonds using transition metal catalysts has recently been reported. ${ }^{11-14}$ Two effective radical perfluoroalkylations of some electron-deficient alkenes have been recently described: one affords the synthesis of chiral fluorinated aminoacids and peptides, and the other is based on the addition of perfluoroalkyl iodides to electron-deficient alkenes using aqueous 
$\mathrm{Na}_{2} \mathrm{~S}_{2} \mathrm{O}_{3}$ by means of UV irradiation of a high pressure Hg lamp. ${ }^{15,16}$ On the other hand, a Peterson olefination approach provides a rapid route for the olefination of trifluoromethyl ketones to yield 3,3,3-trifluoromethylpropenes. ${ }^{17}$ Regarding heteroarylcompounds the synthesis of perfluoroalkyl-substituted thiophenes and pyrroles, ${ }^{18}$ the perfluoroalkylation of heteroaryl bromides, ${ }^{19}$ and of indoles ${ }^{20}$ have been described using different types of catalysts.

On the other hand, the need to employ "greener" solvents opened the scope of reactions in water $^{21,22}$ and the search for more environmentally friendly catalysts for organic reactions in aqueous media. ${ }^{23}$ We have recently reviewed many non-carbon-centered radicals that are used in water to induce and accomplish several synthetically useful organic transformations. ${ }^{24}$ Herewith, we describe a novel and easy methodology for the synthesis of perfluoroalkyl compounds, based on a radical reaction under thermal initiation by ACCN. This synthesis uses water as solvent; it circumvents the use of transition metals as catalysts and of pollutant organic solvents.

\section{Results and Discussion}

We recently reported a novel methodology for the perfluoroalkylation of alkenes and alkynes in water, by UV-light induced catalysis via a radical pathway, yielding good yields via the procedure depicted in Scheme 1. ${ }^{25}$

$$
\begin{aligned}
& \mathrm{R}^{\prime}+\mathrm{C}_{4} \mathrm{~F}_{9} \mathrm{R} \stackrel{h v, 254 \mathrm{~nm}}{\stackrel{\mathrm{H}_{2} \mathrm{O}}{\mathrm{R}} \mathrm{R}=\mathrm{CH}_{2} \mathrm{OH}, \mathrm{R}^{\prime}=\mathrm{H}} \\
& \mathrm{b}: \mathrm{R}=\mathrm{CH}_{2} \mathrm{Cl}, \mathrm{R}^{\prime}=\mathrm{H} \\
& \mathrm{C}: \mathrm{R}=\mathrm{CN}, \mathrm{R}^{\prime}=\mathrm{H} \\
& \mathrm{d}: \mathrm{R}=\mathrm{CN}, \mathrm{R}^{\prime}=\mathrm{CH}_{3}
\end{aligned}
$$

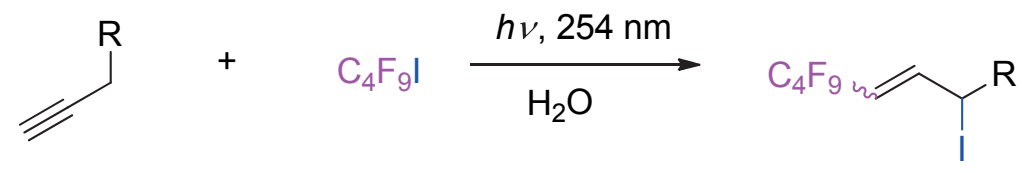
a: $\mathrm{R}=\mathrm{OH}$
b: $\mathrm{R}=\mathrm{Cl}$
c: $\mathrm{R}=\mathrm{C}_{3} \mathrm{H}_{7}$
$\mathrm{d}: \mathrm{R}=\mathrm{N}\left(\mathrm{CH}_{3}\right)_{2}$

Scheme 1. Reaction of alkenes and alkynes with perfluorobutyl iodide. 
The promising results obtained with the above methodology lead us to explore the reaction based on thermal initiation, to avoid the use of quartz-ware thus facilitating the scaling up for preparative purposes. The reaction of two alkenes, 1-dodecene, 1, 1-octene, 2, and two alkynes, phenylacetylene, 3, and 1-hexyne, 4, with two iodides, nonafluoroiodobutane, 5, and tridecafluoroiodohexane, 6, were performed through thermal initiation $\left(\mathrm{ACCN}, 70{ }^{\circ} \mathrm{C}\right.$ ), using bidistillated water as reaction medium, and several conditions trials were performed using 1 as the substrate, and $\mathbf{5}$ as the perfluoroalkyl iodide, to optimize the reaction. The optimal 1:5 molar ratio resulted to be 1:1.7; and the ACCN:1 optimal molar ratio was found to be $0.3: 1$. Only one product, 7, in almost quantitative yield was found, resulting from the addition of the perfluoroalkyl moiety at the terminal carbon, and the iodine at the more substituted vicinal carbon (equation 1).

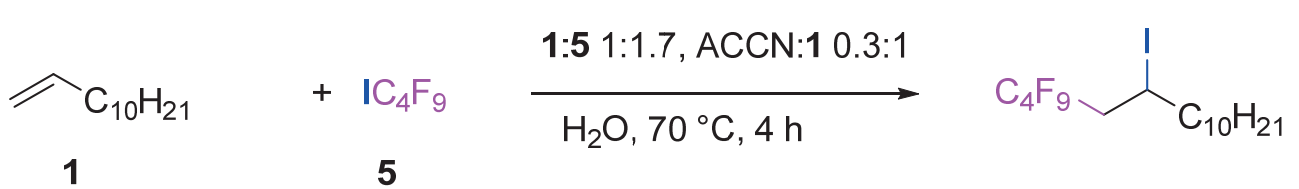

The mixture has to be vigorously stirred throughout the reaction, due that the reactants are not miscible with water. Table 1 shows the results using four unsaturated compounds and two iodides. In each case, the optimal conditions were looked for, the assays were repeated several times, to ensure the best reproducibility. Table 1 shows the eight products synthesized; as can be seen, good or very good yields are obtained, specially for the case of the alkenes. For the alkynes 3 and 4, higher reaction times are needed to complete the reaction, and the yields were slightly lower.

By analogy with other related reactions, a mechanism for the haloperfluoroalkylations of alkenes is described in Scheme 2. ${ }^{26,27}$ In the first step, the azo bond of the radical initiator (ACCN) is thermally broken forming two radicals, that react with the C-I bond of the perfluoroalkyl iodide $\left(\mathrm{R}_{\mathrm{F}} \mathrm{I}\right)$, forming a perfluoroalkyl radical, $\mathrm{R}_{\mathrm{F}}{ }^{*}$. This radical then adds to the double bound of the alkene, at the terminal carbon, forming the more stable secondary radical, $\mathbf{I}$. This new radical abstracts one iodine atom from another molecule of $R_{F} I$, regenerating the $R_{F}{ }^{\circ}$ radical and enabling the addition chain process to occur. In principle, $\mathbf{I}$ could also add to a new molecule of the alkene, forming a polymerization product; this process normally occurs in an extensive manner with highly polymerizable monomers, or with high concentrations of the alkene, and not in the present conditions.

In the case of an alkyne, the mechanism is similar. The alkene radical formed upon the addition of the perfluoroalkyl radical has the possibility of yielding $E$ or $Z$ alkene, depending on the subsequent attack of the $\mathrm{R}_{\mathrm{F}} \mathrm{I}$. Under the present conditions, the $E$ alkene is the main isomer in the reactions of $\mathbf{3}$ and $\mathbf{4}$ (see table 1). 
Table 1. Reaction of unsaturated compounds with perfluoroalkyl iodides
$\mathrm{R}=$
1: $\mathrm{R}=\mathrm{n}-\mathrm{C}_{10} \mathrm{H}_{21}$
2: $\mathrm{R}=\mathrm{n}-\mathrm{C}_{6} \mathrm{H}_{13}$
$+\mathrm{R}_{\mathrm{F}} \mathrm{I}$
$\underset{70^{\circ} \mathrm{C}}{\stackrel{\mathrm{ACCN}, \mathrm{H}_{2} \mathrm{O}}{\longrightarrow}}$

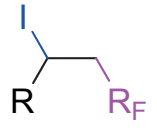
$\mathrm{R}=$
5: $\mathrm{R}_{\mathrm{F}}=\mathrm{n}-\mathrm{C}_{4} \mathrm{~F}_{9}$
3: $\mathrm{R}=\mathrm{Ph}$
6: $R_{F}=n-C_{6} F_{13}$
4: $\mathrm{R}=\mathrm{n}-\mathrm{C}_{4} \mathrm{H}_{9}$

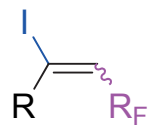

\begin{tabular}{|c|c|c|c|c|c|}
\hline Entry & Substrate & $\mathrm{R}_{\mathrm{F}} \mathrm{I}$ & Molar ratio $^{b}$ & Time (h) & Product, $\%{ }^{\mathrm{c}, \mathrm{d}}$ \\
\hline 1 & 1 & 5 & $1: 1.7$ & 4 & $\mathrm{C}_{4} \mathrm{~F}_{9} \underbrace{\mathrm{C}_{10} \mathrm{H}_{21}} \underbrace{}_{7,99(84)}$ \\
\hline 2 & 1 & 6 & $1: 1.7$ & 4 & $\mathrm{C}_{6} \mathrm{~F}_{13} \underbrace{\mathrm{C}_{10} \mathrm{H}_{21}}_{\mathrm{I}}$ \\
\hline 3 & 2 & 5 & $3: 1$ & 4 & $\mathrm{C}_{4} \mathrm{~F}_{9} \underbrace{\mathrm{C}_{6} \mathrm{H}_{13}}_{\mathbf{9}, 92(82)}$ \\
\hline 4 & 2 & 6 & $3: 1$ & 4 & $\mathrm{C}_{6} \mathrm{~F}_{13} \underbrace{\mathrm{C}_{6} \mathrm{H}_{13}}_{\mathrm{I}} \mathbf{1 0 , 8 2 ( 4 8 )}$ \\
\hline 5 & 3 & 5 & $1: 3$ & 9 & $\begin{array}{r}-{ }^{\xi} \mathrm{C}_{4} \mathrm{~F}_{9} \\
\mathbf{1 1}, 70(63) \\
E: Z 15: 1\end{array}$ \\
\hline 6 & 3 & 6 & $1: 3$ & 9 & $\begin{array}{r}\mathrm{C}_{6} \mathrm{~F}_{13} \\
\mathbf{1 2}, 79(44) \\
E: Z 17: 1\end{array}$ \\
\hline 7 & 4 & 5 & $4: 1$ & 16 & $\begin{aligned} & \mathrm{C}_{4} \mathrm{H}_{9}{ }^{\mathrm{I}} \mathrm{C}_{4} \mathrm{~F}_{9} \\
& 13,71(66) \\
& E: Z 7.7: 1\end{aligned}$ \\
\hline 8 & 4 & 6 & $4: 1$ & 17 & $\begin{array}{r}\mathrm{C}_{4} \mathrm{H}_{9}{ }^{\mathrm{I}} \mathrm{C}_{6} \mathrm{~F}_{13} \\
14,51 \\
E: Z 50: 1\end{array}$ \\
\hline
\end{tabular}

${ }^{\mathrm{a}}$ Reactions carried using $0.15 \mathrm{mmol}$ (38 mg) of ACCN. ${ }^{\mathrm{b}}$ Molar ratio [substrate]:[R $\mathrm{F}$ ]. ${ }^{\mathrm{c}}$ GC yield (isolated yield). ${ }^{\mathrm{d}}$ The $E: Z$ ratio was determined by ${ }^{1} \mathrm{H}-\mathrm{NMR}$. 

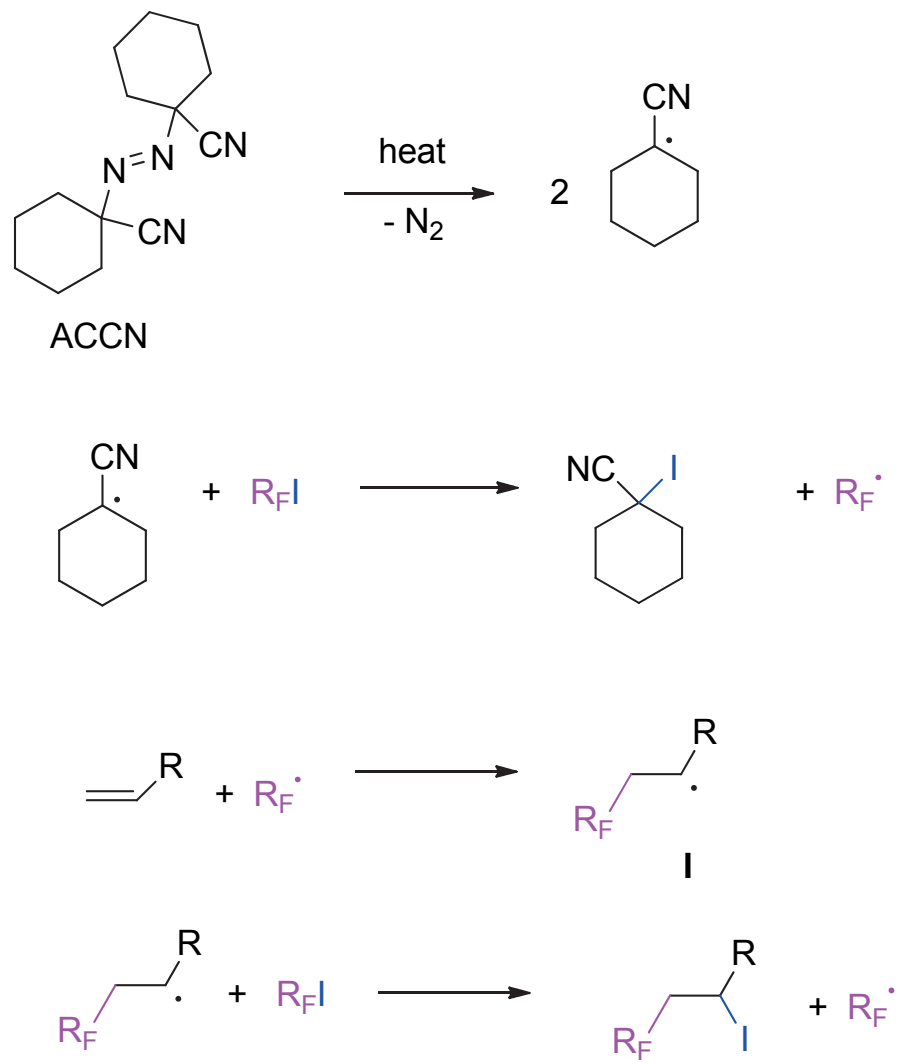

Scheme 2. Chain mechanism for the addition of perfluoroalkyl iodides to alkenes, initiated by ACCN.

The absence of NOE between the phenyl hydrogens and the alkene hydrogen (observed in the NOESY spectra) is consistent with the proposed $E$ geometry. On the other hand, in the ${ }^{1} \mathrm{H}-$ NMR spectra, the triplets due to the olefinic hydrogen (coupled with the $\mathrm{CF}_{2}$ group) of the main isomer appear at lower field than the triplet of the minor isomer. Previous reports of related perfluorosubstituted olefinic compounds show that the signal for the olefinic hydrogen of the $E$ isomer appears downfield, ${ }^{28,29,30}$ which confirms the assignments.

Though compounds 7-14 were synthesized in aqueous media for the first time, it is worthwhile to briefly compare the present results with previous reports on related compounds. $\mathrm{Wu}$ and coworkers ${ }^{31}$ reported a methodology for the addition of polyfluoroalkyl iodides to unsaturated compounds, based on sulfinatodehalogenation. By using a sodium bisulfite or sodium sulfite in DMF aqueous solution as initiator, good yields (38-89\%) of addition to alkenes were obtained after 6-7 hours of reaction time. However, very poor results were observed with alkynes: e.g. the addition product to 1-hexyne was obtained in very low yield, and no addition was observed using phenylacetylene. Perfluoroalkylations of some related alkenes and alkynes have been reported using ferrous bromide as catalyst, in dioxane. ${ }^{13}$ In that case, e.g. compound 11 is obtained with 67\% yield ( $E$ isomer), and compound 9 with 89\% yield. Ogawa and coworkers. ${ }^{28}$ performed the iodoperfluoroalkylation of a variety of unsaturated compounds 
(alkynes, alkenes, allenes and dienes), under light of $\Lambda>300 \mathrm{~nm}$ (using a xenon lamp and Pyrex glassware). The authors reported $99 \%$ and $38 \%$ yields, for the addition of perfluorodecyl iodide to 1-octyne and phenylacetylene, respectively. The three methodologies have the disadvantage of using unfriendly solvents (DMF, dioxane and benzotrifluoride, respectively), and/or somewhat toxic catalysts. In general, in view of the previously mentioned, the synthesis of perfluoroalkyl compounds with our methodology allows similar or better results than related compounds synthesized with other published techniques, with the advantages of greener and in some cases easier methodollogies.

As it is shown in Table 1, the present reaction is very sensitive to the [substrate]:[ $\left.\mathrm{R}_{\mathrm{F}} \mathrm{I}\right]$. In the case of $\mathbf{3}$ and $\mathbf{5}$, if the reaction is carried out using a 3:5 molar ratio of 1:3, 70\% of the addition product $\mathbf{1 1}$ is obtained. Also small quantities of a sideproduct were fomed, that by NMR and MS was shown to be compound 15 (see Scheme 3). On the other hand, if the reaction is carried out using a 3:5 molar ratio of 3:1, 15 becomes the main product, with a $60 \%$ relative yield, thus providing a convenient route for the formation of $\mathbf{1 5}$ as depicted in the Scheme 3.

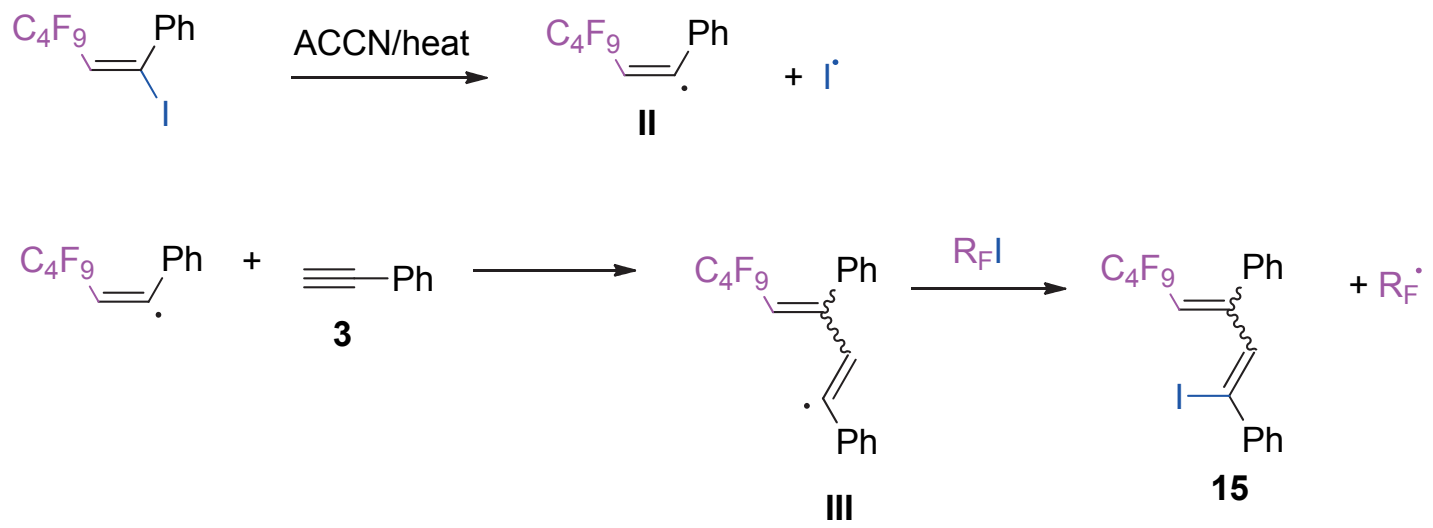

Scheme 3. Proposed mechanism for the formation of 15.

The iodine-carbon bond of the in situ formed $\mathbf{1 1}$ is broken, likely due to the presence of residual ACCN, forming the alkene radical II. This radical adds to another molecule of phenylacetylene, forming the radical III, which by reaction with more $\mathbf{R}_{\mathbf{F}} \mathbf{I}$ affords $\mathbf{1 5}$. The proposed mechanism is consistent with the fact that the excess of $\mathbf{3}$ versus $\mathbf{5}$ markedly increase the formation of $\mathbf{1 5}$. The synthesis of this product should open the way to more elaborated compounds.

\section{Conclusions}

We have reported herewith a novel and convenient methodology for the synthesis of some perfluorosubstituted compounds in water, through the addition of perfluoroalkyl iodides to four unsaturated compounds (1-dodecene, 1-octene, phenylacetylene and 1-hexyne). In the case of the addition to alkynes, alkenes with the $E$ configuration are the main products. In the case of 
addition to alkenes, the products have a suitable iodine atom, able to undergo further reactions. The novelty of this methodology is that it occurs in an ecofriendly solvent, circumvents the use of transition metal reagents or catalysts and occurs under mild conditions.

\section{Experimental Section}

General. Bidistilled water and purified hexane and ethyl acetate, were used to carry out the reactions. 1-dodecene, 2-octene and perfluoroalkyl iodides 5 and $\mathbf{6}$ (Aldrich ) were used without further purification. Phenylacetylene (Aldrich) was distilled under reduced pressure before using. 1-hexyne (Aldrich) was distilled at atmospheric pressure. GC analysis was performed on a Hewlett Packard 5890 Series II gas chromatograph, equipped with a FID detector, and a column type HP-5. The GC quantifications were carried out performing calibration curves, using nundecane as internal standard. ${ }^{1} \mathrm{H},{ }^{13} \mathrm{C}$ and ${ }^{19} \mathrm{~F}-\mathrm{NMR}$ spectra were determined on a Bruker Avance II 500 spectrometer, using a ${ }^{1} \mathrm{H}$ frequency of $500 \mathrm{MHz}$. For the products 11-14, the $E / Z$ ratio was determined by ${ }^{1} \mathrm{H}-\mathrm{NMR}$, based to the integration of the olefinic hydrogens. EI-MS analysis were performed on a Shimadzu QP-5050 GC-MS spectrometer. ESI-HRMS analysis were performed in a Bruker Microtof-QII spectrometer, with a negative and positive mode ESI ionization source. Some difficulties in the determination of the mass spectra of the products 7-10, were faced. Using EI-MS, the molecular ion $\mathrm{M}^{+}$was not detected, being detectable, however, the $[\mathrm{M}-\mathrm{I}]^{+}$ion. This is due, possibily, at the high electron withdrawing capacity of the perfluoroalkyl moiety, that would destabilize the molecular ion. However, using ESI-MS, negative mode, with an ionization potential of $60 \mathrm{eV}$, the signal for the molecular ion could be detected.

Spectroscopical data of compound $\mathbf{1 3},{ }^{25,32}$ is consistent with previously published data for this compound.

\section{General synthetic procedure}

In a glass ampoule, containing a magnetic stirring bar and $38 \mathrm{mg}(0.15 \mathrm{mmol})$ of ACCN, $3 \mathrm{~mL}$ of bidistilled water were added. A septa was settled at the inlet of the ampoule, the water was degassed by a stream of $\mathrm{N}_{2}$ during 5 minutes. The unsaturated compound $(0.5 \mathrm{mmol}$ in the case of 1 and 3,1.5 mmol in the case of 2), and the needed volume of the perfluoroalkyl iodide (according to the molar ratio) was added by means of a syringe. Immediately after the ampoule was flame sealed, and put in a glycerol bath at $70{ }^{\circ} \mathrm{C}$, the mixture was vigorously stirred, until the end of the reaction. In the reactions with the alkyne 4 , due at their high volatility, a hermetic teflon sealed vial, provided with a magnetic stirring bar, was used instead of the flame sealed ampoule, using the same quantity of ACCN and a large excess $(2 \mathrm{mmol})$ of 4 . Upon completion of the reaction, the ampoule or vial was taken out from the bath, allowed to reach r. t., and opened. The reaction mixture was extracted with ethyl acetate ( 3 times). The combined organic phases were dried (anhydrous $\mathrm{Na}_{2} \mathrm{SO}_{4}$ ), filtered to a volumetric flask, and adding the necessary amount of ethyl acetate until a final volume of $50.0 \mathrm{~mL}$. The solution was GC quantified. To 
isolate the products, the solvent was removed under reduced pressure and the residue was purified by silica-gel column, eluting with n-hexane.

1,1,1,2,2,3,3,4,4-nonafluoro-6-iodohexadecane (7). Colorless liquid. ${ }^{1} \mathrm{H}-\mathrm{NMR}\left(\mathrm{CDCl}_{3}, 500\right.$ MHz, ppm): 4.36 (m, 1H), 2.86 (m, 2H), 1.86 (m, 2H), 1.61-1.23 (m, 16H), 0.91 (t, 3H, J 7 Hz). ${ }^{13} \mathrm{C}-\mathrm{NMR}\left(\mathrm{CDCl}_{3}, 125 \mathrm{MHz}, \mathrm{ppm}\right): 41.60$ (t, $\left.J 21 \mathrm{~Hz}\right), 40.38,40.36,31.92,29.58,29.56,29.39$, 29.34, 28.53, 22.71, 20.85, 14.12. ${ }^{19} \mathrm{~F}-\mathrm{NMR}\left(\mathrm{CDCl}_{3}, 470 \mathrm{MHz}\right):-97.11$ (t, 3F, J 8.7 Hz), 129.50 (ddt, 2F, J1 $1330 \mathrm{~Hz}, J 2271 \mathrm{~Hz}, J 314 \mathrm{~Hz}$ ), -140.67 (m, 2F), -142.04 (m, 2F). EI-MS (70 eV). $m / z$ (rel. int. \%): 388 (12), 387( $\mathrm{M}^{+}$- I, 89), 345(26), 331(40), 317(47), 303(41), 289(39), 85(19), 71(64), 69(16), 57(100), 56(13), 55(22). ESI-HRMS (negative mode, $60 \mathrm{eV}$ ) m/z: Calcd. for $\mathrm{C}_{16} \mathrm{H}_{24} \mathrm{~F}_{9} \mathrm{I}\left(\mathrm{M}^{+}\right)$514.0779; found 514.0782.

1,1,1,2,2,3,3,4,4,5,5,6,6-tridecafluoro-8-iodooctadecane (8). Colorless liquid. ${ }^{1} \mathrm{H}-\mathrm{NMR}$ $\left(\mathrm{CDCl}_{3}, 500 \mathrm{MHz}, \mathrm{ppm}\right): 4.36(\mathrm{~m}, 1 \mathrm{H}), 2.89(\mathrm{~m}, 2 \mathrm{H}), 1.82(\mathrm{~m}, 2 \mathrm{H}), 1.62-1.23(\mathrm{~m}, 16 \mathrm{H}), 0.91(\mathrm{t}$, $3 \mathrm{H}, J 7 \mathrm{~Hz}) .{ }^{13} \mathrm{C}-\mathrm{NMR}\left(\mathrm{CDCl}_{3}, 125 \mathrm{MHz}, \mathrm{ppm}\right): 41.70$ (t, $\left.J 21 \mathrm{~Hz}\right), 40.37,40.36,31.92,29.57$, 29.55, 29.38, 29.33, 28.52, 22.70, 20.89, 14.09. ${ }^{19} \mathrm{~F}-\mathrm{NMR}$ (CDCl3, $\left.470 \mathrm{MHz}\right):-96.89$ (t, 3F, J 9 Hz), -129.25 (ddt, 2F, J1 $1321 \mathrm{~Hz}, J 2271 \mathrm{~Hz}, J 314 \mathrm{~Hz}$ ), -137.86 (m, 2F), -138.94 (m, 2F), 139.72 (m, 2F), -142.24 (m, 2F). EI-MS (70 eV). m/z (rel. int. \%): 487( $\left.\mathrm{M}^{+}-\mathrm{I}, 2\right), 403(10)$, 389(11), 99(10), 85(61), 83(11), 71(100), 70(17), 69(35). ESI-HRMS (negative mode, $60 \mathrm{eV}$ ) $m / z$ : Calcd. for $\mathrm{C}_{18} \mathrm{H}_{24} \mathrm{~F}_{13} \mathrm{I} 614.0715\left(\mathrm{M}^{+}\right)$; found 614.0709.

1,1,1,2,2,3,3,4,4-nonafluoro-6-iodododecane (9). Colorless liquid. ${ }^{1} \mathrm{H}-\mathrm{NMR}\left(\mathrm{CDCl}_{3}, 500 \mathrm{MHz}\right.$, ppm): $4.36(\mathrm{~m}, 1 \mathrm{H}), 2.87(\mathrm{~m}, 2 \mathrm{H}), 2.06(\mathrm{~m}, 2 \mathrm{H}), 1.61-1.28(\mathrm{~m}, 8 \mathrm{H}), 0.92(\mathrm{t}, 3 \mathrm{H}, J 6.9 \mathrm{~Hz}) .{ }^{13} \mathrm{C}-$ NMR ( $\left.\mathrm{CDCl}_{3}, 125 \mathrm{MHz}, \mathrm{ppm}\right): 41.57$ (t, $\left.J 20.8 \mathrm{~Hz}\right), 40.35,31.56,29.52,28.18,22.56,20.85$, 14.02. ${ }^{19} \mathrm{~F}-\mathrm{NMR}\left(\mathrm{CDCl}_{3}, 470 \mathrm{MHz}\right):-81.03$ (tt, 3F, J1 $\left.9 \mathrm{~Hz}, J 23.5 \mathrm{~Hz}\right),-113.45$ (ddt, 2F, J1 1330Hz, J2 $273 \mathrm{~Hz}, J 313.9 \mathrm{~Hz}),-124.57$ (m, 2F), -125.91 (m, 2F). EI-MS (70 eV). m/z (rel. int. \%): 331( $\mathrm{M}^{+}$- I, 27), 289(52), 71(10), 69(11), 57(100), 55(45). ESI-HRMS (negative mode, 60 eV) $m / z$ : Calcd. for $\mathrm{C}_{12} \mathrm{H}_{16} \mathrm{~F}_{9} \mathrm{I} 458.0153\left(\mathrm{M}^{+}\right)$; found 458.0149 .

1,1,1,2,2,3,3,4,4,5,5,6,6-tridecafluoro-8-iodotetradecane (10). Colorless liquid. ${ }^{1} \mathrm{H}-\mathrm{NMR}$ $\left(\mathrm{CDCl}_{3}, 500 \mathrm{MHz}, \mathrm{ppm}\right): 4.36(\mathrm{~m}, 1 \mathrm{H}), 2.90(\mathrm{~m}, 2 \mathrm{H}), 1.83(\mathrm{~m}, 2 \mathrm{H}), 1.60-1.25(\mathrm{~m}, 8 \mathrm{H}), 0.92(\mathrm{t}$, $3 \mathrm{H}, J 7 \mathrm{~Hz}) .{ }^{13} \mathrm{C}-\mathrm{NMR}\left(\mathrm{CDCl}_{3}, 125 \mathrm{MHz}, \mathrm{ppm}\right): 41.70$ (t, $\left.J 21 \mathrm{~Hz}\right), 40.36,31.58,29.54,28.20$, 22.56, 20.88, 13.99. ${ }^{19} \mathrm{~F}-\mathrm{NMR}\left(\mathrm{CDCl}_{3}, 470 \mathrm{MHz}\right)$ : -96.92 (t, 3F, J $\left.9.5 \mathrm{~Hz}\right),-129.05$ (ddt, 2F, J1 $1326 \mathrm{~Hz}, J 2271 \mathrm{~Hz}, J 314 \mathrm{~Hz}),-137.88$ (m, 2F), -138.95 (m, 2F), -139.74 (m, 2F), -142.25 (m, 2F). EI-MS (70 eV). $\mathrm{m} / z$ (rel. int. \%): 435(M $\mathrm{M}^{+}$- I, 48), 393(61), 373(15), 353(17), 299(13), 127(11), 97(14), 71(16), 69(23), 65(12), 57(100), 55(68), 53(11), 51(10). ESI-HRMS (negative mode, $60 \mathrm{eV}) \mathrm{m} / z$ : Calcd. for $\mathrm{C}_{14} \mathrm{H}_{16} \mathrm{~F}_{13} \mathrm{I}\left(\mathrm{M}^{+}\right)$558.0089; found 558.0083.

3,3,4,4,5,5,6,6,6-nonafluoro-1-iodo-1-phenyl-1-hexene (11). ( $E$-isomer): Colorless liquid. ${ }^{1} \mathrm{H}$ NMR (CDCl $, 500 \mathrm{MHz}, \mathrm{ppm}): 7.37$ (s, 1H), 7.36 (s, 2H), 7.33 (d, 2H, $J .8 \mathrm{~Hz}), 6.63(\mathrm{t}, 1 \mathrm{H}, J$ $13.5 \mathrm{~Hz}$ ). ( $Z$ isomer: triplet appears at $6.55 \mathrm{ppm}$, with $J 13.4 \mathrm{~Hz}) \cdot{ }^{13} \mathrm{C}-\mathrm{NMR}\left(\mathrm{CDCl}_{3}, 125 \mathrm{MHz}\right.$, ppm): 141.33, 129.31, 128.56, 128.02, 126.91, 126.85 (t, $J 2.7 \mathrm{~Hz}) .{ }^{19} \mathrm{~F}-\mathrm{NMR}\left(\mathrm{CDCl}_{3}, \quad 470\right.$ MHz): -81.07 (t, 3F, $J 9.5 \mathrm{~Hz}),-105.45$ (t, 2F, $J 12.1 \mathrm{~Hz}),-123.81$ (m, 2F), -125.87 (m, 2F). EIMS (70 eV). m/z (rel. int. \%): 448( $\left.\mathrm{M}^{+}, 1\right), 322(11), 321\left(\mathrm{M}^{+}-\mathrm{I}, 55\right), 183(14), 182(69), 152(56)$, 
151(59), 133(30), 102(100), 76(32), 75(15), 74(10), 69(19), 53(11). ESI-HRMS (negative mode, $60 \mathrm{eV}) \mathrm{m} / \mathrm{z}$ : Calcd. for $\mathrm{C}_{12} \mathrm{H}_{6} \mathrm{~F}_{9} \mathrm{I} 447.9371\left(\mathrm{M}^{+}\right)$; found 447.9376.

$\mathbf{3 , 3 , 4 , 4 , 5 , 5 , 6 , 6 , 7 , 7 , 8 , 8 , 8 - t r i d e c a f l u o r o - 1 - i o d o - 1 - p h e n y l - 1 - o c t e n e ~ ( 1 2 ) . ~ ( ~} E$-isomer): Colorless liquid. ${ }^{1} \mathrm{H}-\mathrm{NMR}\left(\mathrm{CDCl}_{3}, 500 \mathrm{MHz}, \mathrm{ppm}\right)$ : 7.40-7.30 (m, 5H), 6.62 (t, $\left.1 \mathrm{H}, J 13.5 \mathrm{~Hz}\right)$. (Z isomer: triplet appears at $6.55 \mathrm{ppm}$, with $J 13.5 \mathrm{~Hz}) .{ }^{13} \mathrm{C}-\mathrm{NMR}\left(\mathrm{CDCl}_{3}, 125 \mathrm{MHz}, \mathrm{ppm}\right): 140.28,128.74$, 128.15, 127.24, 126.56, $126.23(\mathrm{t}, J 2.8 \mathrm{~Hz}) .{ }^{19} \mathrm{~F}-\mathrm{NMR}\left(\mathrm{CDCl}_{3}, 470 \mathrm{MHz}\right):-97.03(\mathrm{t}, 3 \mathrm{~F}, J 9.5$ $\mathrm{Hz}),-121.34(\mathrm{t}, 2 \mathrm{~F}, J 13 \mathrm{~Hz}),-128.55(\mathrm{~m}, 2 \mathrm{~F}),-129.33(\mathrm{~m}, 2 \mathrm{~F}),-130.81(\mathrm{~m}, 2 \mathrm{~F}),-133.83(\mathrm{~m}, 2 \mathrm{~F})$. EI-MS (70 eV). m/z (rel. int. \%): 548( $\left.\mathrm{M}^{+}, 1\right), 421\left(\mathrm{M}^{+}\right.$- I, 64), 183(13), 182(60), 152(50), 151(65), 133(33), 127(12), 119(10), 102(100), 76(24), 75(14), 74(10), 69(46), 63(11), 51(17), 50(15). ESI-HRMS (negative mode, $60 \mathrm{eV}$ ) $\mathrm{m} / z$ : Calcd. for $\mathrm{C}_{14} \mathrm{H}_{6} \mathrm{~F}_{13} \mathrm{I} 547.9307\left(\mathrm{M}^{+}\right.$); found 547.9299.

1,1,1,2,2,3,3,4,4-nonafluoro-6-iodo-5-decene (13). (E-isomer): Colorless liquid. ${ }^{1} \mathrm{H}-\mathrm{NMR}$ $\left(\mathrm{CDCl}_{3}, 500 \mathrm{MHz}, \mathrm{ppm}\right): 6.34$ (t, 1H, J 14.4 Hz), 2.66 (t, 2H, J 7.6 Hz), $1.59(\mathrm{~m}, 2 \mathrm{H}) 1.38(\mathrm{~m}$, $2 \mathrm{H}), 0.97(\mathrm{t}, 3 \mathrm{H}, J 7.3 \mathrm{~Hz})$. ( $Z$ isomer appears at $6.27 \mathrm{ppm}$, with $J 13.2 \mathrm{~Hz}) .{ }^{13} \mathrm{C}-\mathrm{NMR}\left(\mathrm{CDCl}_{3}\right.$, $125 \mathrm{MHz}, \mathrm{ppm}): 126.4$ (t, J $24 \mathrm{~Hz}$ ), 123.09 (t, J 6.4 Hz), 40.94 (t, J 2.7 Hz), 32.17, 21.63, 13.77. ${ }^{19} \mathrm{~F}-\mathrm{NMR}\left(\mathrm{CDCl}_{3}, 470 \mathrm{MHz}\right):-81.06(\mathrm{dt}, 3 \mathrm{~F}, J 111 \mathrm{~Hz}, J 23.5 \mathrm{~Hz}),-107.21$ (dt, 2F, J1 $1455 \mathrm{~Hz}$, $J 212 \mathrm{~Hz}),-124.24(\mathrm{~m}, 2 \mathrm{~F}),-125.84(\mathrm{~m}, 2 \mathrm{~F})$. EI-MS $(70 \mathrm{eV}) . m / z$ (rel. int. \%): 428( $\left.{ }^{+}, 8\right)$, 386(100), 301( $\mathrm{M}^{+}$- I, 21), 273(11), 259(18), 121(12), 103(13), 101(10), 89(12), 83(11), 77(10), 69(22), 65(12), 61(14). ESI-HRMS (negative mode, $60 \mathrm{eV}$ ) $\mathrm{m} / z$ : Calcd. for $\mathrm{C}_{10} \mathrm{H}_{10} \mathrm{~F}_{9} \mathrm{I} 427.9684$ $\left(\mathrm{M}^{+}\right)$; found 427.9690 .

7,7,8,8,9,9,10,10,11,11,12,12,12-tridecafluoro-5-iodo-5-dodecene (14). ( $E$-isomer): Colorless liquid. ${ }^{1} \mathrm{H}-\mathrm{NMR}\left(\mathrm{CDCl}_{3}, 500 \mathrm{MHz}, \mathrm{ppm}\right): 6.35$ (t, $\left.1 \mathrm{H}, J 14.4 \mathrm{~Hz}\right), 2.66(\mathrm{t}, 2 \mathrm{H}, J 7.6 \mathrm{~Hz}), 1.59$ $(\mathrm{m}, 2 \mathrm{H}), 1.38(\mathrm{~m}, 2 \mathrm{H}), 0.97(\mathrm{t}, 3 \mathrm{H}, J 7.3 \mathrm{~Hz})$. (Z isomer appears at $6.16 \mathrm{ppm}$, with $J 12 \mathrm{~Hz}) .{ }^{13} \mathrm{C}-$ NMR (CDCl $, 125 \mathrm{MHz}, \mathrm{ppm}): 126.42$ (t, J $24 \mathrm{~Hz}), 123.04$ (t, J $6 \mathrm{~Hz}), 40.92$ (t, J $2.7 \mathrm{~Hz}), 32.16$, 21.61, 13.76. ${ }^{19} \mathrm{~F}-\mathrm{NMR}\left(\mathrm{CDCl}_{3}, 470 \mathrm{MHz}\right)$ : -80.82 (t, 3F, J 10.4 Hz), -105.46 (t, 2F, $\left.J 13 \mathrm{~Hz}\right)$, $121.70(\mathrm{~m}, 2 \mathrm{~F}),-122.86(\mathrm{~m}, 2 \mathrm{~F}),-123.30(\mathrm{~m}, 2 \mathrm{~F}),-126.17(\mathrm{~m}, 2 \mathrm{~F})$. EI-MS (70 eV). $\mathrm{m} / z$ (rel. int. \%): 528( $\left.\mathrm{M}^{+}, 8\right), 486(100), 401\left(\mathrm{M}^{+}\right.$- I, 23), 381(17), 359(42), 341(10), 313(25), 295(10), 153(10), 127(21), 119(17), 103(33), 90(17), 89(20), 83(12), 77(28), 69(42), 67(10), 65(30), 61(28). ESI-HRMS (negative mode, $60 \mathrm{eV}$ ) $\mathrm{m} / \mathrm{z}$ : Calcd. for $\mathrm{C}_{12} \mathrm{H}_{10} \mathrm{~F}_{13} \mathrm{I} 527.9620\left(\mathrm{M}^{+}\right.$); found 527.9627 .

$\mathbf{5 , 5 , 6 , 6 , 7 , 7 , 8 , 8 , 8 - n o n a f l u o r o - 1 - i o d o - 1 , 3 - d i p h e n y l - 1 , 3 - o c t a d i e n e ~ ( 1 5 ) . ~ ( m a i n ~ i s o m e r ) : ~ s l i g h t l y ~}$ yellow liquid. ${ }^{1} \mathrm{H}-\mathrm{NMR}\left(\mathrm{CDCl}_{3}, 500 \mathrm{MHz}, \mathrm{ppm}\right):$ 7.27-7.13 (m, 10H), 7.21 (s, 1H), 5.52 (t, 1H, $J$ $15 \mathrm{~Hz}$ ). (Minoritary isomer: triplet appears at $6.13 \mathrm{ppm}$, with $J 15 \mathrm{~Hz}$, isomers ratio $4.2: 1) .{ }^{13} \mathrm{C}$ NMR $\left(\mathrm{CDCl}_{3}, 125 \mathrm{MHz}, \mathrm{ppm}\right)$ : 141.9, 141.5, 135.7, 128.5, 128.3,128.3, 128.2, 128.1,128.0, 128.0, 127.8, 117.1 (t, J $21 \mathrm{~Hz}$ ). EI-MS (70 eV). $\mathrm{m} / \mathrm{z}$ (rel. int. \%): $550\left(15, \mathrm{M}^{+}\right), 424(20), 423$ $\left(\mathrm{M}^{+}\right.$- I, 80), 331 (32), 254 (14), 253 (24), 235 (10), 234 (32), 233 (45), 205 (17), 204 (100), 203 (40), 202(17), 151(12), 127(26), 126(11), 117(46), 107(20), 102(23), 101(25), 95(11), 81(10), 77(10), 76(12), 69(32), 55(17), 51(18). ESI-HRMS (negative mode, $60 \mathrm{eV}) \mathrm{m} / z$ : Calcd. for $\mathrm{C}_{20} \mathrm{H}_{12} \mathrm{~F}_{9} \mathrm{I} 549.9850\left(\mathrm{M}^{+}\right)$; found 549.9844 . 


\section{Acknowledgments}

The authors are indebted to the national Research Council (CONICET) and to the Argentine Agency for the Promotion of Science and Technology (ANPCyT) for financial support (PICT 2007/0347).

\section{References}

1. Rahman, M. F.; Peldszus, S.; Anderson, W. B. Water Research 2014, 50, 318-340.

2. Fukuda, S.; Chaussy, D.; Belgacem, M. N.; Reverdy-Bruas, N.; Thielemans, W. Applied Surface Science 2013, 277, 57-66.

http://dx.doi.org/10.1016/j.apsusc.2013.03.174

3. Jaoued-Grayaa, N.; Boughariou-Charrada, B.; Hedhli, A. J. Surfactants and Detergents 2014, 17, 767-772.

http://dx.doi.org/10.1007/s11743-013-1509-6

4. Coope, T.; Moloy, K.; Yake, A.; Petrov, V.; Taylor, C.; Hung, M.; Peng, S. J. Fluorine Chem. 2014, 161, 41-50. http://dx.doi.org/10.1016/j.jfluchem.2014.01.022

5. Hori, H.; Saito, H.; Sakai, H.; Kitahara, T.; Sakamoto, T. Chemosphere 2014, in press.

6. Park, J.-M.; Lee, Y.-H.; Park, H.; Kim, H.-D. J. Applied Polymer Sci. 2014, 131, 40603. http://dx.doi.org/10.1002/app.40603

7. Li, Y.; Su, Y.; Zhao, X.; Zhang, R.; Zhao, J.; Fan, X.; Jiang, Z. J. Membrane Sci. 2014, 455, 15-23.

http://dx.doi.org/10.1016/j.memsci.2013.12.060

8. Zhu, X.; Guo, S.; Jańczewski, D.; Parra Velandia, S. J.; Teo, S. L.-M.; Vancso, G.J. Langmuir 2014, 30, 288-296.

http://dx.doi.org/10.1021/la404300r

9. Yan, Z.; Liu, W.; Wang, H.; Su, K.; Xia-Hou, G. J. Fluorine Chem. 2014, 157, 63-72. http://dx.doi.org/10.1016/j.jfluchem.2013.11.008

10. Mikhaylov, D. Y.; Budnikova, Y. H. Russ. Chem. Rev. 2013, 82, 835-864. http://dx.doi.org/10.1070/RC2013v082n09ABEH004342

11. Xiao, Z.; Hu, H.; Ma, J.; Chen, Q.; Guo, Y. Chinese J. Chem. 2013, 31, 939-944. http://dx.doi.org/10.1002/cjoc.201300433

12. Wallentin, C.-J. ; Nguyen, J. D.; Finkbeiner, P.; Stephenson, C. R. J. J. Am. Chem. Soc. 2012, $134,8875-8884$. http://dx.doi.org/10.1021/ja300798k

13. Xu, T. ; Cheung, C. W.; Hu, X. Angew. Chem. - Int. Ed. 2014, 53, 4910-4914. http://dx.doi.org/10.1002/anie.201402511

14. Takagi, T.; Kanamori, T. J. Fluorine Chem. 2011, 132, 427-429. http://dx.doi.org/10.1016/j.jfluchem.2011.03.001 
15. Yahima, T. J. Synthetic Org. Chem. 2013, 71, 683-693.

http://dx.doi.org/10.5059/yukigoseikyokaishi.71.683

16. Yahima, T.; Jahan, I.; Tonoi, T.; Shinmen, M.; Nishikawa, A.; Yamaguchi, K.; Sekine, I.; Nagano, H. Tetrahedron 2012, 68, 6856-6861.

http://dx.doi.org/10.1016/j.tet.2012.06.028

17. Hamlin, T. A.; Kelly, C. B.; Cywar, R. M.; Leadbeater, N. E. J. Org. Chem. 2014, 79, $1145-$ 1155.

http://dx.doi.org/10.1021/jo402577n

18. Gladow, D.; Reissig, H.-U. J. Org. Chem. 2014, 79, 4492-4502.

http://dx.doi.org/10.1021/jo500534t

19. Mormino, M. G.; Fier, P. S.; Hartwig, J.F. Org. Lett. 2014, 16, 1744-1747. http://dx.doi.org/10.1021/ol500422t

20. Cao, L.; Shen, D.; Wei, J.; Chen, J.; Deng, H.; Shao, M.; Shi, J.; Zhang, H.; Cao, W. European J. Org. Chem. 2014, 2460-2467.

http://dx.doi.org/10.1002/ejoc.201400056

21. Kolvari, E.; Zolfigol, M. A.; Peiravi, M. Green Chem. Lett. \& Rev. 2012, 5, 155-159. http://dx.doi.org/10.1080/17518253.2011.606849

22. Roy, S.; Bhar, S. Green Chem. Lett. \& Rev. 2010, 3, 341-347. http://dx.doi.org/10.1080/17518253.2010.491095

23. Banitaba, S. H.; Safari, J.; Khalili, S. D. Ultrasonic Sonochem. 2013, 20, 401-407. http://dx.doi.org/10.1016/j.ultsonch.2012.07.007

24. Postigo, A.; Nudelman, N. S. Coord. Chem. Rev. 2011, 255, 2991-3030. http://dx.doi.org/10.1016/j.ccr.2011.07.015

25. Slodowicz, M.; Barata-Vallejo, S.; Vázquez, A.; Nudelman, N. S.; Postigo, A. J. Fluorine Chem. 2012, 135, 137-143.

http://dx.doi.org/10.1016/j.ccr.2011.07.015

26. Bravo, A.; Bjorsvik, H.-R.; Fontana, F.; Liguori, L.; Mele, A.; Minisci, F. J. Org. Chem. 1997, 62, 7128-7136.

http://dx.doi.org/10.1021/jo970302s

27. Brace, N. O. J. Fluorine Chem. 1999, 93, 1-25.

28. Tsuchii, K.; Imura, M.; Kamada, N.; Hirao, T.; Ogawa, A. J. Org. Chem. 2004, 69, 66586665. http://dx.doi.org/10.1021/jo0495889

29. Fang, X.; Yang, X.; Yang, X.; Mao, S.; Wang, Z.; Chen, G.; Wu, F. Tetrahedron 2007, 63, 10684-10692. http://dx.doi.org/10.1016/j.tet.2007.07.087

30. Liu, S. Q.; Wang, S. W.; Qing, F.-L. J. Fluorine Chem. 2005, 126, 771-778. http://dx.doi.org/10.1016/j.jfluchem.2005.02.011

31. Wu, F.; Yang, X.; Wang, Z.; Huang, W. J. Fluorine Chem. 2007, 128, 84-86. http://dx.doi.org/10.1016/j.jfluchem.2006.10.001 
32. Habib, M. H.; Mallouk, T. E. J. Fluorine Chem. 1991, 53, 53-60. http://dx.doi.org/10.1016/S0022-1139(00)82238-1 